\section{Prenatal exposure to maternal stress and subsequent schizophrenia}

Sir: Van Os \& Selten (1998) report a higher risk of subsequent schizophrenia in subjects who were in the first and, for males only, in the second trimester of intrauterine life during the May 1940 invasion of The Netherlands. The authors propose that maternal stress may be a shared common pathway to mental disease. We offer an alternative conceptional substrate for the findings.

If May 1940 lies within the first trimester, birth would be between November 1940 and February 1941, therefore including the season of the well-known excess of births of children who later developed schizophrenia (Hare et al, 1974; Bradbury et al, 1985). The specific date of the invasion provides a time anchor against which various environmental influences from conception onwards can be compared. In this case, May being in the northern hemisphere the onset of summer, first-trimester pregnancies will have experienced increasing temperatures, whereas pregnancies in the second trimester in May will have experienced fairly constant cold temperatures during the first weeks of intrauterine life. The higher proportion of affected males found for the presumed exposure by stress in the second trimester, compared with the first trimester, could thus be accounted for by a female-specific protective factor for conceptions at lower temperatures. This would be reflected in births during the third quarter of the year. An unexplained reduction in autumn of births of children who later developed schizophrenia has been found and is of the same magnitude as the excess in the first quarter (Hare et al, 1974; Bradbury et al, 1985).

We propose a yet unexplored line of investigation for clarification of the geneenvironment interactions. The proposal is that of a relationship between early faulty genetic regulation and temperature at the time of conception. The influence of raised temperature at the conception of people who later developed schizophrenia has been explored in some studies (e.g. Templer $\&$ Austin, 1980). Also, it is known that some trinucleotides, including CAG, in the DNA are liable to expansions resulting in hairpin formation of DNA (Gacy et al, 1995). CAG repeats notably occur in the genetic locus of neurodevelopmental disorders including Huntington's disease but are also more frequent in the genome of people with schizophrenia and an excess of CAG has been reported specifically for females with schizophrenia (Morris et al, 1995). Therefore, the genome of the exposed, affected subjects in van Os \& Selten's study could be analysed and compared with the genome of those unexposed and unaffected. If an association with unstable DNA were found, a specific gene-environment interaction for schizophrenia may be assumed, at least for The Netherlands. Undoubtedly, this would be a big step forward and prompts a new approach for the interpretation of schizophrenia in the context of conformational diseases (Carrell \& Lomas, 1997).

Bradbury. T. N. \& Miller, G. A. (1985) Season of birth in schizophrenia: A review of evidence. methodology. and etiology. Psychological Bulletin, 98. 569-594.

Carrell, R.W. \& Lomas, D. A. (1997) Conformationa! disease. Loncet, 350, 134-138.

Gacy, A. M., Goeliner, G., Juranic, N., et al (1995)

Trinucleotide repeats that expand in human disease from hairpin structures in vitro. Cell, 81, 533-540.

Hare, E., Price, J. \& Sinter, E. (1974) Mental disorder and season of birth: a national sample compared with the general population. British journol of Psychiotry. 124. $81-86$.

Morrls, G., Gaitonde, E., McKonna, P. J., et al (1995) CAG repeat expansions and schizophrenia: association with disease in fernales and with early age-at-onset. Humon Molecular Genetics, 4. 1957-1961.

van Os, J. \& Selten, J.-P. (1998) Prenatal exposure to maternal stress and subsequent schizophrenia. The May 1940 invasion of The Netherlands. British journol of Psychiatry, 172. 324-326.

Templer, D. I. Austin, R. K. (1980) Confirmation of relationship between temperature and the conception and birth of schizophrenics. Orthomoleculor Psychiatry, 9 $220-222$.

M. Quenstedt Portsmouth City Drugs and Alcohol Service, Kingsway House, 130 Elm Grove, Portsmouth PO5 ILR

A. Parshall Gordon Hospital, Bloomburg Street, London SWIW 2RH

\section{Evolution of schizotypy}

Sir: Crow (1998) is surely right to suggest that the evolution of schizophrenia was dependent on the evolution of language. He must also be right in saying that language is important for mate recognition, being an integral part of human courtship. The suitor charms his potential mate with both speech and song. The capacity to say "I love you" must have been subject to intensive sexual selection; it is no less wondrous than the peacock's tail.

But language serves another important biological function in man. It is the organ which formulates the ideology of a human group and which thus maintains the cohesiveness of a group by making a sharp boundary between one ideology and another. It acts as a sort of cell membrane, giving human groups a cohesiveness impossible for groups of apes. And just as a cell must divide, so too must a human group divide. The capacity to form a new belief system and reject the belief system of the natal group is characteristic of cult leaders and also of people with schizophrenia (Stevens \& Price, 1996; Price \& Stevens, 1998).

Early psychiatric geneticists were struck by the similarity of schizophrenic thinking to the transcendental preoccupations of prophets, and they examined the possibility that the high esteem in which prophets were held might counteract the reduced fertility of those who ended up as psychiatric patients (Erlenmeyer-Kimling \& Paradowski, 1966). But they rejected the idea, thinking that prophets were ascetic types unlikely to father many children. Now we know differently. Studies of cults (Storr, 1996) have shown that cult leaders may have enormous reproductive opportunities, sufficient to compensate not only for the potential cult leaders who become psychiatric patients, but for the cults which fail either due to harsh external conditions or to features of the new ideology which lead to maladaptive outcomes such as mass suicide.

The implication of this view is that the genetic tendency to schizophrenia, manifested in schizotypy and in cult leaders, is fundamental to human biology and the vital group processes of cohesion and splitting. Schizophrenia may be not so much the price we pay for language, but the price we pay for the harnessing of language in the service of group splitting.

Crow, T. J. (1998) Precursors of psychosis as pointers to the Homo sapiens-specific mate recognition system of language. British journal of Psychiatry, 172, 289-290.

Erlenmeyer-Kimling, L. \& Paradowskj, W. (1966) Selection and schizophrenia. Americon Noturolist, 100. $651-665$.

Price, J. S. \& Stevens, A. (1998) The human male socialisation strategy set: cooperation, defection, individualism, and schizotypy. Evolution ond Humon Behovior. 19, 58-70.

Stevens, A. \& Price, J. (1996) Evolutionory Psychiotry: A New Beginning. London: Routledge.

Storr, A. (1996) feet of Clay: A Study of Gurus. London: Harper Collins.

J. S. Price Herbert Hone Clinic, II Buckingham Road, Brighton BNi 3RA 